\title{
Marteiliosis in molluscs: A review
}

\author{
Franck C.J. Berthe ${ }^{1, a}$, Frédérique Le Roux ${ }^{2}$, Robert D. Adlard ${ }^{3}$ and Antonio Figueras ${ }^{4}$ \\ ${ }^{1}$ Department Pathology and Microbiology, Atlantic Veterinary College, UPEI, 550 University Ave., Charlottetown, \\ Prince Edward Island, C1A 4P3, Canada \\ 2 IFREMER, Laboratoire de Génétique et Pathologie, OIE Reference Laboratory for marteiliosis, EU Community \\ Reference Laboratory for diseases of molluscs, BP 133, 17390 La Tremblade, France \\ 3 Biodiversity Program, Queensland Museum, PO Box 3300, South Brisbane, Queensland 4101, Australia \\ ${ }^{4}$ Instituto Investigaciones Marinas, CSIC, Biologia y Patologia de Organismos Marinos, Laboratorio Nacional \\ Referencia de Enfermedades de Moluscos Bivalvos, Eduardo Cabello 6, 36208 Vigo, Spain
}

Received 24 July 2003; Accepted 20 April 2004

\begin{abstract}
Among mollusc pathogens, paramyxeans are an important group of protistan parasites belonging to the genera Marteilia and Marteilioides. Marteilia refringens and M. sydneyi are of particular concern given their potential impact on mollusc aquaculture world-wide. Aber disease and QX disease are currently listed by the OIE, the World Organisation for Animal Health. After more than thirty years of existence in the scientific literature, these organisms still pose questions and research challenges to investigators. This paper reviews current knowledge of the group and key references. The review was focused on taxonomy, epidemiology, pathology and potential control methods for these organisms in order to enhance understanding of paramyxean infection issues in mollusc aquaculture.
\end{abstract}

Key words: Taxonomy / Epidemiology / Pathology / Diagnosis / Paramyxean parasites

Résumé - Marteiliose des mollusques : une synthèse. Au nombre des agents pathogènes des mollusques, les paramyxéens, notamment les agents appartenant aux genres Marteilia et Marteilioides, sont des protistes parasites des plus importants. Marteilia refringens et $M$. sydneyi constituent un souci majeur compte tenu de leur impact potentiel sur la conchyliculture dans le monde. La maladie des Abers et la maladie du Queensland (QX) sont actuellement répertoriées par l'Office International des Epizooties. Après plus de trente années d'existence dans la littérature scientifique, ces organismes posent encore questions et défis aux investigateurs. Cet article fait l'état des connaissances sur le sujet en s'attachant plus particulièrement à la taxonomie, l'épidémiologie, la pathologie et les méthodes potentielles de contrôle de ces organismes dans l'optique d'une meilleure compréhension de la problématique des paramyxéens en conchyliculture.

\section{Introduction}

Paramyxean parasites are an important group of protists infecting various groups of marine invertebrates. Currently grouped in the phylum Paramyxea, these organisms, particularly those included in genera Marteilia (Grizel et al. 1974) and Marteilioides (Comps et al. 1986) have been emphasised in the scientific literature due to their detrimental effect on commercially exploited molluscs. However, paramyxeans span a wide range of hosts such as crustaceans, annelids and molluscs and their bio-diversity is probably underestimated considering the little attention given to parasites of invertebrates in marine environment.

The type species of the genus Marteilia, Marteilia refringens, has caused recurring mass mortalities of the edible

\footnotetext{
a Corresponding author: fberthe@upei . ca
}

flat oyster, Ostrea edulis, in Europe since its discovery in the late 1960s (Herrbach 1971; Grizel et al. 1974; Alderman 1979; Grizel 1985). Marteilia refringens, as the agent of Aber disease, and M. sydneyi, agent of QX disease of Sydney rock oyster, Saccostrea [commercialis] glomerata, in Australia (Perkins and Wolf 1976), are major concerns for oyster aquaculture. Similarly, Marteilioides chungmuensis (Comps et al. 1986) is increasingly recognised as a serious pathogen of the Pacific oyster, Crassostrea gigas, in Japan and Korea. Marteilia refringens and $M$. sydneyi are listed as notifiable to the Office International des Epizooties, the World Organisation for Animal Health (OIE 2003).

Following recent progress in scientific knowledge of these parasites since Figueras and Montes (1988), a revised and updated review of marteiliosis was warranted, with particular emphasis on taxonomy, epidemiology, pathology and potential control methods in mollusc aquaculture. 


\title{
a - Phylum Ascetosporea Sprague 1978 \\ Class 1 Stellatosporea Sprague 1978 \\ unicellular spores, spore wall interrupted by an apical orifice, 3 genera : Minchinia, Haplosporidium, and Urospidium
}

Class 2 Paramyxea Levine 1980

multicellular spores made of cells enclosed inside each other with production of cells by endogeneous budding

\author{
Order 1 Paramyxida Chatton 1911 \\ presumed meiosis with elimination of a polar globule, 1 genus Paramyxa \\ Order 2 Marteiliida Desportes and Ginsburger Vogel 1977 \\ meiosis not yet observed, 2 genera Marteilia, Paramarteilia.
}

\section{b - Phylum Paramyxea Desportes and Perkins 1990}

sporulation results from series of internal cleavages within an ameboid stem cell that germinates from spores in tissues of invertebrate marine animals. Development is characterised by production of offspring cells that remain inside the parent cell.

Class 1 Marteiliidea Desportes and Ginsburger-Vogel 1977

with three genera, Marteilia, Paramarteilia, and Marteilioides

Class 2 Paramyxidea Chatton 1911

presumed meiosis with elimination of a polar globule, with one genus, Paramyxa.

Fig. 1. a - Phylum Ascetospora Sprague 1978 as proposed by Desportes in 1981; b - Phylum Paramyxea as proposed by Desportes and Perkins (1990).

\section{The palimpsest of paramyxean taxonomy}

The taxonomic history of Marteilia refringens and its relatives has known a long period of controversy, although recently, this situation has become more settled, gaining from DNA sequencing.

Early descriptions of Marteilia refringens came out through series of papers (Comps 1970; Herrbach 1971; Bonami et al. 1971; Grizel et al. 1974). It had initially been classified in the fungal order of Chytridiales (Herrbach 1971), then was included in the Microspora or the lower fungi (Grizel et al. 1974), and later in the Labyrinthomyxa (Grizel and Tigé 1977). The genus Marteilia has also been linked with either the haplosporidians because of the presence of membrane bounded granules similar to haplosporosomes (Comps 1970; Perkins 1976) or the myxosporeans due to the process of development characterised by pluricellularity and early individualisation of somatic elements (Desportes and Ginsburger-Vogel 1977; Desportes and Lom 1981). Corliss (1984), reviewing the kingdom Protista, considered the phylum Ascetospora, created by Sprague (1979) including Haplosporea and Paramyxea, as a polyphyletic assemblage requiring more study (Fig. 1a). Desportes and Perkins (1990) undertook the work and proposed a separate phylum, Paramyxea, embedding the genera Marteilia, Paramarteilia and Paramyxa (Fig. 1b).

More recently, the small subunit rDNA gene of Marteilia refringens was sequenced and phylogenetic analysis performed (Berthe et al. 2000). This provided support for the description of the phylum Paramyxea described by Desportes and Perkins (1990). Results indicate that M. refringens is not closely related to any single eukaryotic phylum whose SSU rDNA sequence is currently known. Results confirmed that $M$. refringens is not related to the Myxosporea, or to the haplosporidians. However, further analysis of molecular data produced evidence that the Haplosporidia are an order in the phylum Cercozoa (Cavalier-Smith and Chao 2003a,b), and Haplosporidia and Paramyxea are separate orders in the phylum Cercozoa. This position is controversial and other analyses show that Haplosporidia are related to Cercozoa, as a sister taxon, but not within Cercozoa (Burreson, pers. comm.). Although support values are very low (Marteilia shares a single nucleotide deletion with Haplosporidium and Minchinia species), Cavalier-Smith and Chao consider that M. refringens is a haplosporidian, which would consequently invalidate Paramyxea. Interestingly, this un-restful taxonomic history could face new developments in the near future. Based on this unique SSU rDNA sequence, the phylogenetic analysis suggests an early evolutionary origin of Paramyxea (Berthe et al. 2000). Such a basal topology drawn from rDNA analysis is increasingly recognised as a potential artefact due to variation in the rate of molecular evolution among eukaryotic taxa (Peyretaillade et al. 1998; Stiller et al. 1999). Earlyemerging lineages would have evolved much faster than most other eukaryotes, as is often found with parasitic organisms. The impact of such high evolutionary rates, making identification of the relationship of Paramyxea with other organisms extremely uncertain, could be modulated when increasing the number of sequences available for phylogenetic analysis (Itoh et al. 2003; Kleeman et al. 2004; Putinaowarat, Taveekijakarn, Somsiri and Berthe, unpubl. data). In comparable situations, sequencing of other genes of phylogenetic interest also proved 
very valuable to better understand the evolutionary origin of a group of protists (Hirt et al. 1999) and similar work should probably be undertaken with representatives of Paramyxea.

Paramyxea are defined by sporulation resulting from series of internal cleavages within an amoeboid stem cell that germinates from spores in tissues of invertebrate marine animals. Development is characterised by production of offspring cells that remain inside the parent cell. Mature spores consist of several cells enclosed inside each other and delimited by a continuous wall with no operculum or orifice (Desportes and Perkins 1990). Currently, the phylum Paramyxea embeds two classes (Fig. 1b): Marteiliidea, consisting of three genera, Marteilia (Grizel et al. 1974), Paramarteilia (GinsburgerVogel and Desportes 1979); and Marteilioides (Comps et al. 1986) and Paramyxidea including a unique genus, Paramyxa (Chatton 1911).

The genus Marteilia encompasses several species. Marteilia refringens was observed in the flat oysters, Ostrea edulis, O. angasi, O. puelchana, O. chilensis (Grizel et al. 1974; Grizel et al. 1982; Pascual et al. 1991; Bougrier et al. 1986), and the blue and Mediterranean mussels, Mytilus edulis and M. galloprovincialis (Tigé and Rabouin 1976; ClaverDerqui 1990; Villalba et al. 1993). Marteilia refringens cells were also found in the Pacific cupped oyster, Crassostrea gigas (Cahour 1979; Montes et al. 1998) and, presumably, the American oyster, C. virginica (Renault et al. 1995). However, these findings were not associated with viable infections and could be interpreted as atypical locations of the parasite in filter feeding organisms. Another species of the genus Marteilia, M. maurini, was described in blue and Mediterranean mussels, Mytilus galloprovincialis, M. edulis, from France (Comps et al. 1982; Auffret and Poder 1985). In Australia, Marteilia sydneyi was described in the Sydney rock oyster, Saccostrea glomerata (see Perkins and Wolf 1976). Lastly, the species Marteilia christenseni was described in peppery furrow, Scrobicularia [piperata] plana by Comps (1983) on the Atlantic coast of France, and M. lengehi in the hooded oyster, Saccostrea cucullata, from the Persian Gulf (Comps 1976) and, possibly, Australia (Hine 1996).

This list of species in the genus Marteilia should not be regarded as definitive given that several unaffiliated isolates were reported and validity of these species is still under question.

To illustrate this, in Europe, unidentified Marteilia, given as Marteilia sp., were observed in the cockle, Cardium edule, Venus clams, Tapes rhomboides and T. pullastra (Comps et al. 1975; Poder et al. 1983; Figueras et al. 1996), the razor clams, Ensis minor and E. siliqua (Ceschia et al. 2001), the horse mussel, Modiolus modiolus, and blue and Mediterranean mussels, Mytilus edulis, M. galloprovincialis (Comps et al. 1975; Poder et al. 1983; Auffret and Poder 1985; Ceschia et al. 1991; Figueras et al. 1991) although, these last reports may refer to isolates of M. maurini. Other cases of Marteilia infection in molluscs were also reported from the calico scallop, Argopecten gibbus, in Florida (Moyer et al. 1993), and the giant clam, Tridacna maxima, in Fiji (Norton et al. 1993). More recently, paramyxean organisms related to Marteilia were observed in the rock oyster, Saccostrea forskali, from Thailand (Putinaowarat, Taveekijakarn, Somsiri and Berthe, unpubl. data) and the black-lip pearl oyster, Pinctada margaritifera,

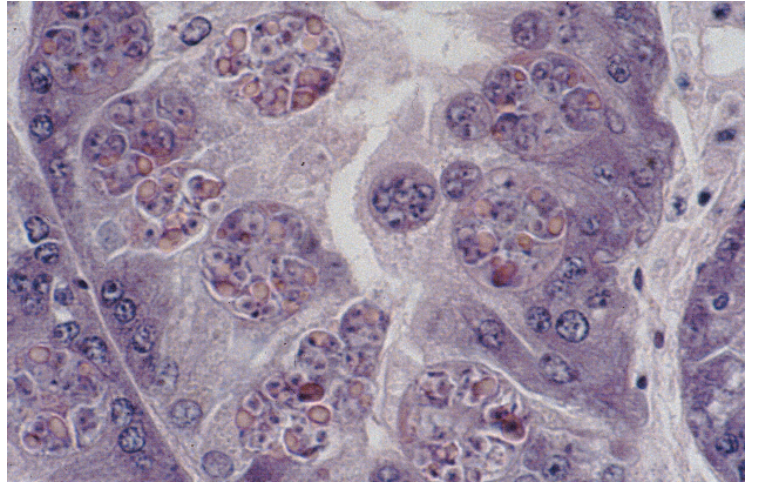

Fig. 2. Marteilia refringens, advanced stages in the digestive diverticula of a flat oyster, Ostrea edulis. Light microscopy, H, E stain, $\times 1000$.

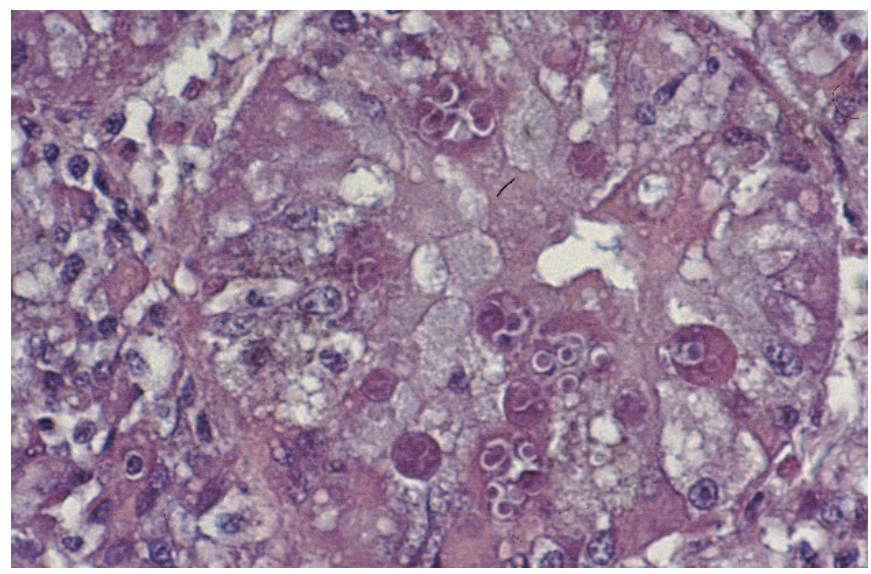

Fig. 3. Marteilia maurini in the digestive diverticula of a Mediterranean mussel, Mytilus galloprovincialis. Light microscopy, $\mathrm{H}$, E stain, $\times 1000$.

from Australia (Jones and Berthe, unpublished data). It may be anticipated that more species should arise as mollusc aquaculture and concomittant mollusc pathology data continues to develop in the world.

In spite of numerous papers reporting Marteilia species in molluscs, the question of taxonomic relationships and species delineation is still open to debate. The diagnosis of these isolates was based mainly on histological features, ultrastructural characteristics and host specificity (Figueras and Montes 1988). Host specificity as a distinguishing character for species of Marteilia was discarded when M. refringens was found in Mytilus galloprovincialis, there was some doubt that M. maurini, which was described as the only Marteilia species parasitising mussels, was actually a different species from $M$. refringens. While $M$. refringens and $M$. sydneyi show no cross reaction in immuno-assays using antibodies (Anderson et al. 1994), available monoclonal and polyclonal antibodies directed against Marteilia isolated from Mytilus edulis cross react with European isolates (Tiscar et al. 1993; Robledo et al. 1994; Berthe, unpubl. data) and their electrophoretic protein profiles in SDS PAGE never provided clear evidence for discrimination (Berthe and Renault, unpubl. data). In a recent study, ultrastructural criteria used for Marteilia 


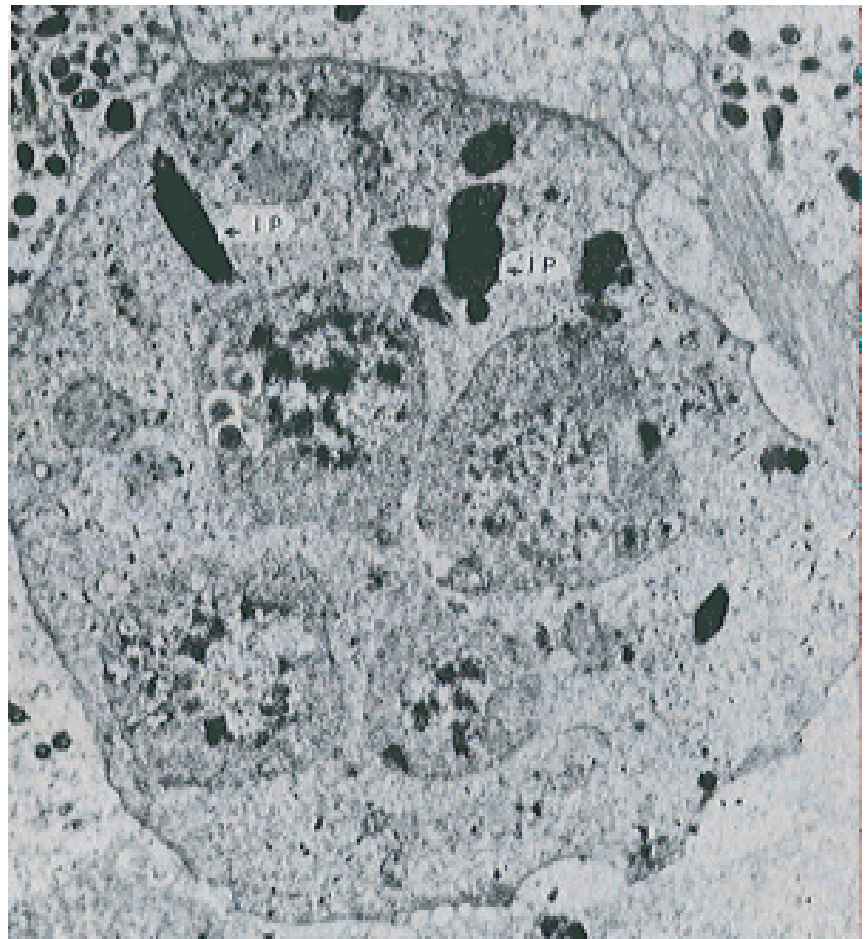

Fig. 4. Primary cell of Marteilia refringens containing four secondary cells. Paracristallin inclusions (IP) are observable. TEM $(\times 12000)$. From Grizel et al. (1974).

identification, with particular emphasis on haplosporosomes, striated plate-like inclusions and spore wall morphology, were challenged, leading to the conclusion that Marteilia maurini from Mytilus edulis and M. galloprovincialis could not be separated from Marteilia refringens from Ostrea edulis on this basis (Longshaw et al. 2001). The conclusion of these authors is that such criteria are invalid. As such, it was proposed to consider $M$. maurini as a junior synonym of $M$. refringens. A similar conclusion was reached based on sequences of the rDNA gene small subunits of Marteilia spp., isolated from oysters and mussels (Berthe et al. 2000). However, authors, led by epidemiological and pathological considerations (Figueras and Robledo 1993; Berthe et al. 1998; Le Roux et al. 2001), conducted further study, targeting internal transcribed spacer region (ITS1) of the rRNA gene. The palinode appeared as sequences, proved to be clearly dimorphic, and distribution of the two genetic types of Marteilia linked to the host species, oysters and mussels respectively (Le Roux et al. 2001). Part of this study was based largely on the newly re-described Marteilia maurini from Mediterranean mussels, Mytilus galloprovincialis, in Croatia (Zrncic et al. 2001). Considering this result in a polyphasic approach, they supported the recognition of two species of Marteilia in Europe, M. refringens and $M$. maurini. However, since these results were published, an increasing number of reports, noticeably in the Iberian Peninsula, show that no strict correlation of Marteilia types to mussels or oysters can be established (Lopez-Flores et al. 2004) and that M. maurini (M type) can be found in oysters and $M$. refringens (O type) in mussels in contrast to what was shown earlier (Le Roux et al. 2001). Practical implications of these findings are discussed later in this paper.

As stated above, class Marteiliidea consists of the genera Marteilioides and Paramarteilia (Ginsburger-Vogel and Desportes 1979), in addition to the genus Marteilia (see Grizel et al. 1974). Two species are known within the genus Marteilioides. An ovarian parasite, Marteilioides chungmuensis, is reported from several locations in Pacific regions where Pacific oyster, Crassostrea gigas, is cultured (Comps et al. 1986, 1987; Park and Chun 1989; Itoh et al. 2002). Although formerly described by Comps and collaborators in 1986, this species was apparently identified earlier, in various papers, as an amoeba-like pathogen in the gonad of oysters collected along the south coast of Korea (Chun 1970, 1972 and 1979) and Japan (Matsuzato et al. 1977). Also, protists incertae sedis were recorded in C. gigas in USA (Becker and Pauley 1968) that could be interpreted as M. chungmuensis (see Hine 1996). Similarly, a protistan parasite in the ova of the blacklipped oyster, Saccostrea echinata (see Wolf 1977) could possibly be M. chungmuensis which has been recorded since then in Australia (Hine 1996). More recently, occurrence of a Marteilioides-like organism in Japanese carpet shell, Tapes philippinarum, in southern coast of Korea was also reported (Lee et al. 2001). Another species of the genus, Martelioides branchialis, was described from Sydney rock oysters, Saccostrea glomerata, in Australia (Anderson and Lester 1992).

With the genus Paramarteilia, we move from molluscs to crustaceans as hosts. Paramarteilia orchestiae is a parasite of the amphipod species Orchestia gammarellus, O. mediterranea and O. aestuarensis (see GinsburgerVogel et al. 1976; Desportes and Ginsburger-Vogel 1977a,b; Ginsburger-Vogel and Desportes 1979a,b; Ginsburger-Vogel 1991). However, it may be speculated that several bona fide species could exist in the genus Paramarteilia.

Within the phylum Paramyxea, exists the class Paramyxidea (Fig. 1b), including a unique genus, Paramyxa (Chatton 1911). Paramyxa paradoxa is a parasite of planktonic larvae of the polychaete annelid, Poecilochaetus serpens (see Chatton 1911; Desportes and Lom 1981). Although this organism shares common features with members of the class Marteiliidae, it mainly differs by displaying a cell division step interpreted as chromatic reduction leading to the production of a haploid sporoplasm (Desportes 1981).

Efforts developed to tackle the systematics of these organisms, and the emphasis given to taxonomy and phylogeny of paramyxeans, may be surprising. However, these efforts are driven by two major concerns. Among these organisms, some are responsible for mass mortality and economic losses in mollusc aquaculture. It is therefore of the utmost importance to be able to diagnose them accurately to provide a scientific basis for health management programmes (Berthe et al. 1999). Development of diagnostic tools that are specific and sensible is a central question which is likely to be addressed through clarified classification of Marteilia and related species. Another point to make here is that because of a complex life cycle of Marteilia species (Berthe et al. 1998), probably involving other marine invertebrates, knowledge of paramyxean 
occurrence in marine environments appears essential. These questions are discussed later in this paper.

\section{Protean diseases caused by Marteilia spp. and paramyxean parasites}

As it was previously said, paramyxean parasites may have detrimental effect on their hosts. Marteilia refringens is the causative agent of Aber disease which provokes mass mortality of the flat oyster, Ostrea edulis, in Europe (Alderman 1979; Grizel 1985). Similarly, Marteilia sydneyi is responsible for QX disease in Sydney rock oyster, Saccostrea glomerata, in Australia (Perkins and Wolf 1976; Adlard and Ernst 1995). These agents are regarded as major concerns for mollusc aquaculture and are listed by the Office International des Epizooties (OIE 2003). Marteilioides chungmuensis (see Comps et al. 1986) is also a serious pathogen of the Pacific oyster, Crassostrea gigas, the importance of which, in the global mollusc aquaculture production, is high. Basically, paramyxeans have various effects on their host via two major target systems, digestive and reproductive, which we wish to review here. Interestingly, recent investigations on Marteilia refringens show that the digestive gland in the oyster and ovary in the copepod are successively both targeted by the parasite during its life cycle (Audemard et al. 2002).

Exceptions exist. Marteilioides branchialis causes multifocal lesions (1-2 mm in diameter) in the gills linked to proliferation of the gill lamellae epithelial cells, and with an associated haemocytic infiltration by granulocytes (Anderson and Lester 1992). Actual impact of the parasite on the host is not fully understood (Anderson et al. 1994), and the parasite has not been reported since its original description. In giant clam, Tridacna maxima, Marteilia sp. was described in the kidney of infected animals where it induces chalk-white, cyst-like foci (Norton et al. 1993). Cysts apparently arise from proliferation of the ciliated epithelium of the kidney ducts. Although this Marteilia-like organism could be pathogenic to its host, similarly no report of its occurrence has been made since its initial description.

Paramyxa paradoxa is located in the digestive epithelium of Poecilochaetus serpens and causes hypertrophy of mitochondria and nuclei of host cells, associated with a progressive clearing of the cytoplasm (Desportes 1981). Spores of P. paradoxa are liberated into the lumen of the digestive tract of its host, when sporogenesis is achieved, and degeneration of the epithelial cells of the host is reported (Desportes and Lom 1981).

Pathological effects in paramyxean hosts have been extensively described for Marteilia refringens in the oyster, Ostrea edulis, and mussels, Mytilus spp. as well as M. sydneyi in the oyster, Saccostrea glomerata.

Digestive tropism is a feature of infections with $M$. sydneyi with the host oyster showing interesting symptoms. They include poor condition factor and shrunken body, often presenting as general translucency of the body of infected oysters. Death is attributed to direct blockage of the digestive gland by the parasite and consequent host starvation (Wolf 1979). Similar observations were made in the case of Marteilia refringens in the oyster, Ostrea edulis (see Grizel et al. 1974;
Grizel 1985). The presence of the parasite in the host reduces the condition index (Figueras et al. 1991). In the terminal stages of the disease, exhausted oysters are no longer capable of closing their shell (His et al. 1976). Marteiliosis affects oysters during the summer period, which in Europe begins in May, peaks from June to August, and decreases in December (Grizel 1985; Audemard et al. 2001), while in Australia it begins in January with infection peaking in February and mortalities occurring through to April or May (Adlard, pers. obs., Peters and Raftos 2003).

The digestive gland, in which M. refringens and other Marteilia species occur, is a site of intracellular food digestion and one of the main sites for storage of metabolic reserves (Robledo et al. 1995a). In heavy infections, M. refringens significantly reduces absorption of organic matter (Camacho et al. 1997). Severe infections may also cause loss of condition as a consequence of reduced energy acquisition. Furthermore, the parasite may interfere directly with host feeding and absorption simply by its physical presence. Development of adipo-granular storage cells in the mantle of Mytilus galloprovincialis was shown to be inhibited in the presence of M. refringens (Villalba et al. 1993b). Apparently, $M$. refringens also interferes with glycogen storage in Ostrea edulis (see Robert et al. 1991).

Mature spores of Marteilia spp. are released into the environment via the lumen of the digestive tubules and intestine. This release is associated with destruction of the host digestive gland epithelia with tissues of the secondary digestive tubules of $M$. galloprovincialis and $O$. edulis almost totally destroyed by the release of Marteilia spores (Robledo and Figueras 1995; Alderman 1979).

In the course of infection by Marteilia sydneyi, a significant reduction of phenoloxydase activity was noted, suggesting that inhibition by the parasite could facilitate development of the disease (Peters and Raftos 2003). This phenoloxydase cascade is a component of the defence mechanisms of the host. Despite many studies, still little is known about mollusc immunity (Roch 1999; Berthe 2002). Molluscs possess an innate, non adaptive immune system employing a large variety of circulating molecules involved in response to non-self invasion. Circulating cells can also mount phagocytic, cytotoxic or inflammatory responses. Epithelial hyperplasia, hypertrophy and fusion of gill filaments, and infiltration of haemocytes are observed during initial infection by $M$. sydneyi (see Kleeman et al. 2002a). Plasmodia primordia of M. refringens and $M$. maurini are located in the stomach wall where they are associated with limited ciliary and tissue disruption, increased secretions of mucus (Figueras et al. 1991). Plasmodia within the epithelia of the stomach wall or primary digestive tubules do not induce any particular haemocytic reaction. However, located in the gills, plasmodia primordia may be associated with a heavy infiltration of haemocytes in the surrounding area of the gill where the parasite was present (Robledo and Figueras 1995). The 4 plasmodia found were between 11 and $15 \mu \mathrm{m}$ in the longest axis, contained a nucleus, and had a form resembling sporangial primordium. The parasites seemed to be inside the epithelial cells of the gills. As the infection progresses, variable amounts of haemocyte infiltration may be observed in primary and secondary digestive tubules (Alderman 1979; 
Robledo and Figueras 1995). In Mytilus galloprovincialis, focal and massive concentrations of haemocytes described as granulocytomas may occur along with tissue necrosis (Villalba et al. 1993a). Infection by M. refringens may cause significant increase of haemocytes in the haemolymph (Carballal et al. 1998).

However, the effect of Marteilia spp. on their hosts is highly variable and may be rather inconspicuous as reported in the case of M. maurini in Mytilus edulis (Auffret and Poder 1985) or M. refringens in O. edulis (Grizel et al. 1974; Alderman 1979; Grizel 1985) suggesting an apparent lack of severe reaction to a high load of parasitic cells.

This protean picture of marteiliosis could, however, have an explanation. In most of these papers a major, uncertainty lies in the identification of the Marteilia species under consideration and this is highlighted in recent data on M. refringens and M. maurini host affinities in Europe (Le Roux et al. 2001). More attention should be paid to actual affiliation of Marteilia isolates in further studies. Another point to raise here is that apparently mussels may have different susceptibility based on their genetic origin as recently shown in a study of different mussel populations (Fuentes et al. 2002). Hybrid mussels, M. edulis x M. galloprovincialis, show lower viability in a Marteilia endemic area. Hybrids have also a lower level heat shock protein (HSP) 70, as well as the stress protein calreticulin. In the same study, best performance was obtained from native $M$. galloprovincialis populations. Interestingly, one of the very few outbreaks of mussel mortality caused by marteiliosis in France in the past years occurred after transplantation of British mussels, M. edulis, into the Aber Benoit, France, a zone where Marteilia refringens and M. maurini are present. While this population was experiencing nearly $100 \%$ mortality and infection with $M$. maurini, local mussel populations were healthy, displaying no sign of disease and low levels of infection (Le Roux, unpubl. data; Berthe 2002). A very similar situation occurred in the Thau lagoon, France, when transplanting Norwegian flat oysters, O. edulis (Pichot, pers. comm.).

Other cases of Marteilia infection should be mentioned here. Marteilia christenseni does not appear to provoke any strong reaction in its host, Scrobicularia plana (Comps 1985). While early plasmodial forms of $M$. refringens in C. gigas only occasionally cause haemocytic infiltration (Cahour 1979). Focal, haemocyte infiltration of the connective tissue was noted in the digestive gland and digestive diverticula epithelia associated with a Marteilia-like infection in C. virginica (Renault et al. 1995). Infection of the scallop, Argopecten gibbus, by Marteilia sp. is associated with shrunken adductor muscles, gaping shells, and withdrawn mantles that slowly respond to tactile stimulation (Moyer et al. 1993). The parasites do not induce notable haemocytic response. Interestingly, in very heavy infections, the host had utilised its own tissues by catabolism, a process by which scallops derive energy when unable to extract sufficient energy from food intake. Death is attributed to starvation of the infected scallops.

Gametogenesis and gonadal development are reduced or delayed in infected oysters, O. edulis (Robert et al. 1991) and mussels, M. galloprovincialis (Figueras et al. 1991; Villalba et al. 1993b). Heavily infected individuals may reach the point of being unable to start a new gametogenic cycle in the following year. On the other hand, spawning stress itself may enhance the progression of the disease (Villalba et al. 1993b).

Combining all or some of these symptoms eventually leads to the death of the host. Mortality rates may be very high in the case of Marteilia refringens and $M$. sydneyi.

Marteilia refringens also displays a tropism for ovarian tissue in its copepod host, Paracartia grani, during its life cycle (Audemard et al. 2002). Observations were made on female juvenile (copepodid) and adult stages, while $M$. refringens was never detected in male copepods. Infections of the ovaries in copepods by microsporidian parasites has been described (Andreadis 1988; Micieli et al. 2000) which apparently do not seriously alter normal metabolic processes, although no experimental data are available in the case of Marteilia refringens. In Paracartia grani, ovarian tissue was frequently overwhelmed by $M$. refringens in the form of large numbers of small cells within the ovocytes (Audemard et al. 2002). This apparent large number of parasitic cells produced in the copepod may increase the probability for the parasite to encounter the next host during its life-cycle. Observed stages of $M$. refringens morphologically appear different from the known stages observed in oyster digestive gland, although further transmission electron microscopy studies are needed. This ovarian location and intra-cellular position of M. refringens may be surprising. However, when located in the gills of mussels, plasmodia primordia seemed to be inside the epithelal cells of the gills (Robledo and Figueras 1995). Also, other paramyxean parasites are known to target gonads of marine invertebrates: $M$. chungmuensis in $C$. gigas and $P$. orchestiae in Orchestia gammarellus.

Paramarteilia orchestiae induces chitinous nodules under the epidermis of its crustacean host, O. gammarellus (Ginsburger-Vogel and Desportes 1979a). Parasitism with P. orchestiae apparently does not affect growth rates, longevity nor reproductive ability of the host; however, a feminising effect is noted in which genetic males were either transformed into females or produced intersex males (Ginsburger-Vogel 1991). This was demonstrated by grafting infected sexual organs into non-infected animals and inducing intersexuality.

Marteilioides chungmuensis is also an ovarian parasite, affecting Pacific oyster, C. gigas (see Chun 1979; Comps et al. 1986, 1987). The impact of M. chungmuensis on reproduction cycle of oyster is still unclear. According to Park and Chun (1989) there is no clear evidence of any harmful effect of the parasite on its host, although infected Pacific oysters develop lumps or nodule-like gonads on their body during spawning season. Such macroscopic lesions and abnormal appearance of oysters are unacceptable in the market, resulting in serious economic losses. Parasitic cells of M. chungmuensis are usually distributed inside the ovary and located within the oocytes. In heavy infections, accumulation of haemocytes within or bounding around the follicle walls are noted (Ngo et al. 2003). Infected eggs may be retained in the ovarian follicle or shed into the environment through the gills. Observation of seasonal changes in prevalence and infection intensity by $M$. chungmuensis in the annual reproductive cycle of $C$. gigas suggests that infection may cause spawning failure by delaying spawning and destroying ripe oocytes. 


\section{Development of Marteilia spp. in their respective hosts}

Unsurprisingly, paramyxeans use various routes of development in their respective hosts, although they share commonalties. Continuous enlargement of the primary cell cytoplasm and, within it, increase in the number of daughter cells by serial endogenous budding and cell division, characterise the development of paramyxeans.

This development usually starts with the production, within the primary cell or stem cell, of a variable number of secondary cells (1-4 for P. paradoxa, 2-3 for $M$. chungmuensis, 8 for $M$. refringens, 1-12 for $P$. orchestiae and 8-16 for $M$. sydneyi). It is a matter of conjecture whether the earliest visible stages in the host are uninucleate stem cells which undergo a division producing a single secondary cell within a cytoplasmic vacuole (Desportes 1981). Alternatively, due to its small size, thin sections of the primary cell might miss the secondary cell (Perkins 1988). As such, excystment from the spore wall of the tri-cellular spore of $M$. refringens would release the earliest primary/secondary cell stage. The outermost sporoplasm of the mature spore would degenerate while middle and innermost sporoplasms would become the primary and secondary cell, respectively. Ultrastructural arguments exist to support this when considering the presence of vermiform haplosporosomes in the middle sporoplasm of $M$. refringens and $M$. sydneyi, and similarly within the primary cell. The secondary cell and innermost sporoplasm share an absence of haplosporosomes. In addition, the outermost sporoplasm is often degenerated in mature spores (Perkins 1988).

Paradoxically, many cells containing secondary and tertiary cells are observed but very few uninucleate stem cells are observed. Different hypotheses were proposed to address this. Stem cells could proliferate to give rise to many stem cells before producing secondary cells. Such a developmental route was hypothesised by means of a schizogonial stage (Franc 1980; Grizel 1985). Another possibility is that the primary cell containing a single secondary cell might proliferate and then undergo sporulation (Perkins 1993). However, this multiplication has not been observed so far. Recent observations indicate a possible two-way development of secondary cells, either producing propagules, or incrementing local infection (Audemard et al. 2000; Berthe unpubl. data).

The two phases of development which are common to all genera of paramyxeans are production of a number of secondary cells and tertiary cells by internal cleavage, followed by production of sporoplasm cells within the tertiary cells by series of endogenous buddings to produce the characteristic cellwithin-cell structure, eventually producing spores or propagules (Desportes and Perkins 1990). Throughout development of the parasite there is a concomitant enlargement of the primary cell cytoplasm to accommodate the increasing number of cells. In the case of $M$. refringens, the size of the primary cell ranges from 7 to $35 \mu \mathrm{m}$, depending on the number of daughter cells it contains (Grizel 1985). However, mononucleated cells were noted measuring between 4.5 and $23 \mu \mathrm{m}$ (Franc 1980).

The primary cell nucleus divides by mitosis and produces a smaller second nucleus surrounded by a thin cytoplasmic layer.
This nuclear division is characterised by the disruption of the nuclear membrane into vesicles which then fuse end-to-end to envelope both nuclei. The secondary cell then divides to produce two identical cells. Further divisions produce a number of secondary cells which varies depending on the genera and species within the phylum. The second phase of sporulation is characterised by production of a varied number of tertiary cells within the secondary cells by internal cleavage. Each tertiary cell in turn cleaves to produce propagules with a variable number of sporoplasms (2 for Paramarteilia orchestiae, 3 for Marteilioides chungmuensis and Marteilia spp., 4 for Paramyxa paradoxa), each of them being located in a vacuole within the other.

Extensive description of $M$. refringens development in oyster is given by Grizel et al. (1974) and Grizel (1985). The parasite evolves from early stages, which are usually observed in the epithelia of the upper digestive tract, mainly palps and stomach (Grizel et al. 1974), and more rarely in the gills (Comps 1970; Robledo and Figueras 1995). The sporulation process takes place within the epithelium of the digestive gland tubules. Sporangia are released in the lumen of the digestive tract (Perkins 1976; Alderman 1979) and this phenomenon is often associated with destruction of digestive gland epithelia. Sporangia are shed into the environment within the faeces of infected oysters. The development of the parasite in flat oysters is seasonal. In winter and early spring, Marteilia refringens is usually absent or found in small numbers in the host. Sporangia primordia correspond to a chronic infection all year long (Balouet 1979), while mature stages correspond to seasonal stages probably responsible for the spread of the disease. Apparently the seasonal cycle of Marteilia refringens is partially ruled by temperature (Grizel and Tigé 1977; Balouet et al. 1979; Berthe et al. 1998; Audemard et al. 2001).

Although the initial stages of Marteilia sydneyi also enter through the gills and palps, further development is rather different from its antipodean equivalent, $M$. refringens (Kleeman et al. 2002a). An extrasporogonic proliferation step results in the liberation of parasitic cells into the connective tissues and haemolymph resulting in a systemic infection. Later, infection of the digestive gland occurs and nurse cells initiate the characteristic cell-within-cell proliferation. This developmental process may explain the strong host response noted in the course of QX disease as stated above.

Less documented is the development of Marteilioides chungmuensis in the Pacific oyster (Park and Chun 1989; Imanaka et al. 2001; Itoh et al. 2002). Development stages other than sporulation stages in the ovary are currently unknown. The parasite apparently invades immature ova that move towards the centre of the follicle during their development. The growth of the parasite is correlated with the growth and maturation of hosting ovocytes (Itoh et al. 2002). Spores or propagules could be released into the environment through the genital canal. Recent advances in the development of molecular tools and their potential use on M. chungmuensis should facilitate investigation on vegetative and infective stages of the parasite and shed new light on this disease (Itoh et al. 2003). 


\section{Dr Jekyll and Mr Hyde: Life-cycle of Marteilia refringens and its alternative hosts}

The most well known part of Marteilia refringens lifecycle is its development within the host Ostrea edulis. In numerous papers published on this paramyxean parasite and on M. sydneyi from Australia, the existence of a complex lifecycle had been postulated, although its transmission routes and life-cycle was unknown and until now remains uncertain (Balouet 1979; Balouet et al. 1979; Lauckner 1983; Grizel 1985; Figueras and Montes 1988; Berthe et al. 1998; Kleeman and Adlard 2000; Audemard et al. 2000, 2002).

Early field observations led authors to suspect the involvement of other host species in the transmission of M. refringens (see Balouet 1979; Balouet et al. 1979; Grizel 1985; Lester 1986). Direct transmission of Marteilia refringens between oysters, $O$. edulis, by co-habitation and by injection and feeding of spore suspensions has been unsuccessful despite numerous attempts (Balouet 1979; Balouet et al. 1979; Perkins 1988; Grizel 1985; Berthe et al. 1998), and similarly, feeding with spores and transplantation of digestive gland infected with M. sydneyi failed to infect naive oysters, S. glomerata (see Lester 1986). This flurry of negative results discharged the horizontal transmission hypothesis in favour of the existence of an heteroxenous life-cycle. However, counterpoints exist in a unique, positively successful experimental transmission to mussels, M. galloprovincialis, using a suspension of $M$. refringens obtained by mashing infected digestive gland of oysters, O. edulis (Comps and Joly 1980).

Implication of filter-feeding or bottom-feeding fish or invertebrates rather than scavengers has been suggested given that $M$. sydneyi sporonts are released into the environment prior to death of the host rather than after its death (Roubal et al. 1989). However, the feeding of fish with large numbers of spores did not result in infection, the spore apparently passing through the gut. Grizel (1985) suggested that spores of $M$. refringens may need a period of maturation in seawater or sediments prior to becoming infective. In the case of $M$. sydneyi, an experimental study demonstrated that spores are short-lived once shed in the environment (Wesche et al. 1999). This study also suggests that there is no evidence that birds or fish play a role in the life-cycle or dispersion of the parasite when considering the lack of survival of ingested spores after about two hours.

Feeding of M. refringens spores to Crangon crangon, Carcinus maenas and Marinogammarus marinus (Van Banning 1979) has also been a failure; so has a different approach looking for possible infective stages in animals collected in M. refringens endemic areas (Balouet et al. 1979). Ultrastructural examination of Spirorbis spp., Polydora spp., Pomatoceros triqueter, Crepidula fornicata, Galathea squamifera, Liocarcinus puber and Carcinus maenas, as well as plankton samples failed to reveal the presence of $M$. refringens stage. These studies were strongly impeded by the technical limits of histology, electron microscopy and immunohistochemistry as screening tools, and complicated by the thousands of species present in endemic areas (Balouet et al. 1979; Grizel 1985; Berthe et al. 1998).
The problem of species diversity was circumvented by choosing particular oyster ponds, named claires, in the Marennes-Oléron Bay (Berthe et al. 1998; Audemard et al. 2001). Environmental characteristics of claires strongly limit the number of inhabiting species as compared with intertidal areas and oyster beds. As a result of this, claires host less than 100 recognisable species (Reymond 1991; Audemard et al. 2001), versus more than 1000 on open shores in the same region (de Montaudouin and Sauriau 2000).

In addition, based on the sequence of the SSU rRNA gene of $M$. refringens, specific polymerase chain reaction primers and in situ hybridisation probes were designed and molecular tools allowing the detection of Marteilia DNA developed (Le Roux et al. 1999; Berthe et al. 2000). PCR and in situ hybridisation represent powerful tools for the detection of the parasite in potential hosts, because they are sensitive, rapid and independent of both developmental stages of the parasite and location in host species (Mialhe et al. 1995). PCR was first used to screen every species sampled in the claire ponds for the presence of the parasite and identified the copepod Paracartia (Acartia) grani as a potential host of $M$. refringens (Audemard et al. 2002). The presence of the parasite in the ovarian tissues of $P$. grani was confirmed using in situ hybridisation. In the same study, transmission experiments from $O$. edulis to $P$. grani were successful, demonstrating that these two species are contiguous in the life cycle of the parasite. First attempts of reverse transmission failed. Design of this experiment should be improved, mainly by enhancing the inoculum of $M$. refringens. This could be achieved by either improving the transmission rate from oysters to copepods reared in the laboratory or relying on better environmental conditions to increase naturally the prevalence in copepod populations.

Involvement of $P$. grani in the life cycle of $M$. refringens appears consistent with both the ecology of this copepod and the epidemiology of the disease. Paracartia grani is mainly observed in spring and summer as it is in the claire ponds where it may represent $100 \%$ of the total copepod abundance. Also, the seasonal cycle of $M$. refringens matches the life cycle of $P$. grani, as it was shown that parasite transmission occurs during summer (Grizel and Tigé 1977; Grizel 1985; Audemard et al. 2002). During winter, sporangia primordia of $M$. refringens observed in flat oysters do not develop. In spring, increase of water temperature fosters M. refringens development (Balouet 1979; Berthe et al. 1998). Similarly, $P$. grani is absent from the water during winter and reappears in spring from resting benthic eggs. These eggs could act as a reservoir for the parasite and this should be studied in future investigations. The geographical range of P. grani also fits $M$. refringens distribution. In Europe, marteiliosis has been reported to be restricted to north-western Brittany, the Bay of Biscay and the Mediterranean Sea, including the Atlantic coasts of Spain and the Adriatic coasts of Italy and Croatia. $P$. grani is a warm temperate species originating from the tropical and temperate Atlantic coast. This calanoid copepod is a typical species of coastal, semi-confined ecosystems, conditioned by instability of both physical parameters (temperature and salinity) and biological conditions (quality and quantity of available food). This species is often observed in the vicinity of oyster beds and has been observed within the geographical 
range of the disease; in estuaries or bays where the parasite has been reported (Audemard et al. 2002).

It has been demonstrated that, at least, two species are involved in the life cycle of $M$. refringens: oyster, $O$. edulis and copepod, Paracartia grani. However, the actual role of $P$. grani in the life cycle of $M$. refringens requires further investigation. Furthermore, it should be noted that studies were conducted under experimental conditions and results should be validated in natural intertidal zones. Also, molecular typing of Marteilia in the copepod by PCR-RFLP indicates that both $M$. refringens and $M$. maurini can occur (Le Roux, unpubl. data). Is $P$. grani an intermediate or alternative host for $M$. refringens, or does it play a role in life-cycle of the two paramyxeans?

While we still have little knowledge about the biology of $M$. refringens, the life-cycle of other paramyxeans is even less understood although recent advance in the development of molecular detection tools should, in the near future, enable investigators to go forward on this topic (Kleeman and Adlard 2000; Itoh et al. 2003).

\section{Diagnosis of marteiliosis in molluscs}

For many pathogens of molluscs, available techniques are rather limited, and investigations restricted to histological and ultrastructural examinations (Miahle et al. 1995). While many pathogens are difficult to detect and recognize using such methods, paramyxeans are usually easily diagnosed, at a generic level, by applying simple methodologies such as stained tissue imprints and histology. However, there is a need for diagnostic tools discriminating between the different genera and species of paramyxean, given the potential economic impact of these organisms. The effective control of marteiliosis, as with most mollusc diseases, requires access to diagnostic tests that are specific, rapid, reliable and sensitive (Berthe et al. 1999; Cunningham 2002). Also, we already emphasised the tremendous potential of new detection tools for elucidating the life-cycle of these parasites. Recent efforts to address these issues have led to the development of immunoassays and nucleic acid based diagnostic methods. These techniques offer the advantages of high sensitivity and high specificity, and possible rapid screening of aquatic organisms for the presence of a pathogen. Development of molecular methods was possible since purification protocols of the parasite from its host tissues was established (Miahle et al. 1985; Robledo et al. 1995; Itoh et al. 2003).

A number of papers have described antibody-based diagnostic assays for Marteilia spp. (Roubal et al. 1989; Tiscar et al. 1993; Anderson et al. 1994; Robledo et al. 1994a; Pernas et al. 2000). An indirect fluorescent antibody test (IFAT) was used for M. sydneyi detection with polyclonal antibodies (Roubal et al. 1989). It has been shown, by immuno-gold labelling under TEM, that the antibodies bound to the secondary cell membrane, refringent granules, spore wall as well as haplosporosomes of $M$. sydneyi. Interestingly, no cross reaction was detected with Myxosporea isolated from fish caught in areas near the oyster beds (Roubal et al. 1989). Another IFAT incorporating a polyclonal antibody against $M$. sydneyi was later described (Anderson et al. 1994) and proved to be specific to $M$. sydneyi when tested against $M$. refringens,
M. maurini, Marteilia sp. and Marteilioides branchialis. A polyclonal antibody specific to Marteilia sp. from mussels, M. galloprovincialis, and binding to the spore structure was developed (Tiscar et al. 1993). However, difficulty of using polyclonal antibodies in routine diagnosis is recognised. Monoclonal antibodies against Marteilia sp. purified from mussels, M. edulis, were produced (Robledo et al. 1994a). These antibodies were demonstrated to be specific for European isolates of the parasite as they did not cross react against $M$. sydneyi (Anderson et al. 1994). A major problem associated with the use of antibodies until now was the lack of specificity and consequent risk of misidentification (Robledo et al. 1994a; Pernas et al. 2000). However, considering recent progress in the clarification of paramyxean taxonomy, immuno-assays may still have the potential to be useful tools.

To date, gene probes used in the diagnosis of marteiliosis in cultured molluscs have been developed for detection of the most economically important paramyxeans, namely Marteilia refringens (Lubat 1990; Le Roux et al. 1999, 2002), M. sydneyi (Anderson et al. 1995; Kleeman and Adlard 2000) and M. chungmuensis (Itoh et al. 2003). These techniques are slowly moving from development in specialized laboratories for research purposes, to routine application and are expected to find an increasing use in routine marteiliosis monitoring programs in mollusc aquaculture and in efforts to prevent the spread of paramyxeans. International standards proposed by the OIE are currently including these methods for the detection and identification of Marteilia refringens and $M$. sydneyi (OIE 2003). DNA is a useful molecule to target for diagnostic procedures because its sequence does not usually vary with the life stage or developmental phase of the pathogen or with the host or tissue location. This is of particular interest considering that, apparently, European Marteilia spp. do not have a tight host specificity. On the other hand, the routine use of DNA based diagnostic techniques is hampered by a number of problems, which may result in false positive, or false negative results (Walker and Subasinghe 2000; Cunningham 2002).

Not all regions of the DNA, however, are equally useful as targets for probes and/or PCR primers. Closely related organisms, such as Marteilia refringens and M. maurini for example (Le Roux et al. 2000) or M. refringens and M. sydneyi (Kleeman et al. 2002), have a high degree of sequence similarity, making the development of specific probes and primers difficult. The development of species specific molecular diagnostic tools will be facilitated as sequences for more genes and pathogens become known. Often, however, when DNA sequences have been determined by different laboratories they do not correspond to the same gene or region of a gene, impeding taxonomic studies and sequence comparisons for the development of diagnostics. Efforts were made to obtain the same regions of sequences from related organisms to optimize the chance of developing probes and PCR primers with the desired specificity and in the case of paramyxeans, efforts have focused on the small-subunit ribosomal RNA gene (Le Roux et al. 1999, 2002; Berthe et al. 2000; Kleeman and Adlard 2000; Itoh et al. 2003). These rRNA genes are useful targets for diagnostic tests because there are many copies in the genome, which can help to ensure good sensitivity, and they offer a mosaic of conserved and variable regions which allow analyses 
at various levels of resolution. The available sequences are used for phylogenetic studies to help clarify the taxonomy of these parasites. However, in order to minimize the possibility of species-specific molecular diagnostics failing to detect a particular strain of a pathogen, as many strains as possible from a wide geographic range should be sequenced.

A three tier examination procedure is currently recommended by the Office International des Epizooties, which includes screening, presumptive and confirmation methods. Surveillance of marteiliosis is routinely performed by histology or digestive gland imprints. Histology provides a large amount of information such as presence of concomitant pathogens, pathological conditions, host reactions or loss of condition following spawning. Usual staining procedure is based on Hemalun Eosin (Howard and Smith 1983; Thoeson 1994). When topographical staining with $\mathrm{H} \& \mathrm{E}$ is used, nuclear and basophilic structures stain a blue to dark purple colour, the endoplasmic reticulum stains blue, while the cytoplasm takes on a grey colour. The acid dye eosin stains the other structures pink. This staining technique is simple and reproducible and, although it only allows a limited differentiation of cell structures, it is possible to detect paramyxeans and any abnormalities in tissue and cellular structure. Other techniques may be applied to demonstrate particular structures or features as required such as Millot's trichrome etc. (Gutierrez 1977). The young stages of Marteilia refringens are present in the epithelia of the stomach, intestine and digestive ducts. Initial infective stages of Marteilia sydneyi are present in the epithelia of palps and gills and presporulating stages are found in the connective tissues and the epithelia of the digestive tubules, digestive ducts, intestine and stomach. Sporulating stages of $M$. refringens and M. sydneyi can be found in the epithelia of the digestive gland tubules. Free sporangia can also be observed in the lumen of the intestine. The unique feature of internal cleavage to produce cells within cells during sporulation differentiates Marteilia spp. from all other protista. In tissue imprints, the parasite is $5-8 \mu \mathrm{m}$ in size in the early stages and may reach up to $40 \mu \mathrm{m}$ during sporulation. The cytoplasm of the cells stains basophilic, the nucleus is eosinophilic; the colour may vary slightly with the stain used. The secondary cells or sporoblasts are surrounded by a bright halo.

When abnormal mortality outbreaks occur, presumptive diagnostic methods such as tissue imprints, squashes or smears can be used in addition to histology because of the quick answer provided by these techniques. Also in this case, Polymerase Chain Reaction (PCR) can be usefull for producing sensitive and specific results (Walker and Subasinghe 2000; Cunningham 2002). In addition, amplification of DNA fragments and subsequent sequence analysis can help to identify an unknown pathogen and even confirm infections in a different host. Problems with PCR are that light infections may be missed if tissue is subsampled or inhibitory factors in mollusc tissues give false negative results. This has been discussed when applying PCR as a screening method for alternative host detection (Audemard et al. 2002). In addition, the extreme sensitivity of PCR may result in a positive result even when a viable pathogen is not present; and positive and negative controls as well as internal controls must be included in the protocols (Le Roux et al. 1999).

When a pathogen is encountered in the course of routine surveillance or mortality outbreak studies, transmission electron microscopy (TEM) may be necessary for specific identification. Limitations of this technique has been discussed earlier (Longshaw et al. 2001), although Marteilia sydneyi can be differentiated from $M$. refringens by means of TEM. Thus, a pop off technique for reprocessing histological sections for electron microscopy may be valuable (Kleeman 2002). Recognised criteria are a lack of striated inclusions in the plasmodia of $M$. sydneyi, formation of 8 to 16 sporangial primordia in each plasmodium (instead of 8 for $M$. refringens), occurrence of two spores (rather than two or three, Adlard pers. obs.) in each sporangium (rather than four in M. refringens), and the presence of a heavy layer of concentric membranes surrounding mature $M$. sydneyi spores. In situ hybridisation has been proposed to detect infections and confirm the identity of paramyxean parasites in a histological section (Le Roux et al. 1999; Kleeman and Adlard 2000; Itoh et al. 2003). Probes have different levels of specificity, depending on the region of the genes where they have been designed (Kleeman et al. 2002b). With regards to the potential use of in situ hybridisation, it is important that laboratories, with appropriately fixed tissue, archive this material in case it is needed for retrospective studies. Again, there is a need for standard and validated protocols (Berthe et al. 1999; Berthe 2000; Kleeman et al. 2002), and protocols should include negative and positive controls (Le Roux et al. 1999). PCR based methods may also be used for confirmation. For example, to differentiate $M$. refringens from M. maurini, polymorphism among the PCR products is identified by testing for cleavage with restriction enzyme $\mathrm{HhaI}$ (Le Roux et al. 1999). The resulting restriction fragments are analysed electrophoretically on $2 \%$ agarose gels. The profile corresponding to $M$. maurini gives three bands of $156+157$ and $68 \mathrm{bp}$, respectively, whereas the profile corresponding to $M$. refringens gives two bands of 226 and $156 \mathrm{bp}$, respectively.

Detailed protocols for Marteilia spp. diagnosis are provided by the OIE Manual for diagnostic of aquatic animal diseases; this manual is permanently reviewed and updated (OIE 2003; http://www . oie.int/eng/normes/fmanual/ A_summry.htm).

\section{Health management in mollusc aquaculture with regards to marteiliosis}

Management of marteiliosis is an obvious central concern for mollusc aquaculture as outbreaks are recognised as a significant constraint to aquaculture production and trade, affecting both economic development and socio-economic revenue. In France, between 1980 and 1983, the conjunction of marteiliosis and bonamiosis outbreaks have resulted in economic losses evaluated at 240 millions of Euros turnover and 200 million Euros added value and induced a cut down of $20 \%$ of direct employment (Grizel in Launey 2001).

Molluscs are unique with regards to health management and, indeed, there are very few ways to reduce the detrimental effect of pathogens in mollusc aquaculture. Molluscs are usually reared in the open sea which strongly limits the potential 
use of chemotherapy, because of the quantity of product to be used, its impact on the environment and the obvious risk of re-infection. Equally, vaccination does not provide an option since molluscs do not posses B/T type lymphocytes and do not produce antibodies.

Pathogen transfers via movements of aquatic organisms appear to be an important underlying cause of such epizootics. One of the very few ways to reduce the impact of such pathogens on commercially exploited bivalves is to establish effective programs to prevent the transfer of infected stocks. The primary method of control is by restriction of the movement of infected animals to areas known or suspected to be free of either Marteilia (OIE 2002) or Marteilioides (Elston 1993; Bower et al. 1994). It has been reported that M. refringens was successfully controlled in the Netherlands by a combination of routine monitoring and oyster farming restriction in the Yerseke Bank where all infected oyster stocks were either harvested or destroyed (Van Banning 1988). Although seen as a paradigmatic case of health management, the most probable explanation is that the parasite may not have had the capacity to close its life cycle (Audemard et al. 2002). While a region or country where molluscs are infected with any of these pathogens should not be allowed to export into another area free of this disease, access to diagnostic tests that are rapid, reliable and sensitive is of a central importance. Again, marteiliosis poses a problem with the possible occurrence of M. refringens in mussels (Le Roux et al. 2002). Whether mussels can play a role in the dissemination of the disease has yet to be established. Until now, experimental attempts to tackle this question have failed due to a scarcity of co-infection events (Berthe unpubl. data). In order to overcome this difficulty, an epidemiological study based on a risk approach is currently underway.

In endemic zones, reducing the impact of pathogens is likely to rely on knowledge of their biology (temperature and salinity tolerance, life-cycles, presence of intermediate or reservoir hosts, routes of transmission, to name a few) and genetic improvement of host species for disease resistance. In the latter case, further knowledge of molluscan defence mechanisms is likely to provide significant prospects for controlling host-pathogen relationships (Berthe 2001). To date, few attempts to develop disease resistance to Marteilia spp. by genetic selection have been made although observations suggest that the biological basis exists (Fuentes et al. 2002). In Australia, preliminary reports on resistance to $M$. sydneyi through mass selection of surviving hosts have been made (Nell et al. 2000), with first generation improvement recorded but additive resistance of successive generations yet to be confirmed. Peters and Raftos (2003) correlated physiological immuno-suppression (a drop in levels of the protein phenyloxidase) to infection with $M$. sydneyi. In addition, Newton et al. (2004) showed that oysters with a level of resistance to marteiliosis had higher phenyloxidase (PO) activity and they identified a novel form of PO which may contribute to enhanced immune defence in selected stock. These studies may lead to the provision of a genetic marker which can be used with confidence to secure commercially viable levels of resistance to marteiliosis.
Recent data obtained on the biology of $M$. refringens may also lead to new developments in management strategies based on a better understanding of life-cycle of the parasite (Berthe et al. 1998; Audemard et al. 2001, 2002). By planting and harvesting oysters outside the time period when they are most likely to become infected with $M$. refringens, the risk of marteiliosis can be significantly reduced. In endemic areas, oyster seed and juvenile oyster planting should be curtailed from June and August as this is the transmission period of M. refringens (Tigé and Grizel 1977; Perkins 1993). Similarly, oysters at risk from $M$. sydneyi, in the southern hemisphere, should not be planted during the period from January to March and harvested before the late December (Bower et al. 1994). Given the role of copepods in $M$. refringens transmission, a more fine tuned strategy could probably be established by mapping the geographical and temporal distribution of these species. Waters under oceanic influence could be used for temporary stocking. Development of $M$. refringens is ruled by temperature and salinity. It could therefore be controlled by growing and holding oysters in high salinity waters (Grizel 1985; Bower et al. 1994) or possibly in low temperature waters as a threshold of $17{ }^{\circ} \mathrm{C}$ is required to establish new infections of M. refringens in oysters (Grizel 1985; Berthe et al. 1998; Audemard et al. 2001, 2002). On the other hand, in the case of M. sydneyi, observations indicate that outbreaks are not correlated with fluctuations in $\mathrm{pH}$, salinity and water temperature in close proximity to the oysters (Anderson et al. 1994b; Wesche 1995). Practical implementation of this scientific information may be difficult due to current constraints of farming practices. Modelling the dynamics of the disease would be valuable for more effective management at the broad scale.

Although treatments show little promise in the control of mollusc diseases, various methods aimed at control of Marteilia spp. have been suggested and tested. Chemicals such as methylene blue, malachite green and furanace have been attempted but failed to kill $M$. refringens in infected oysters, O. edulis (Grizel 1979). It was also attempted to eradicate $M$. sydneyi from its natural host, $S$. glomerata, by immersion or injection of either pyrimethamine and sulphadoxine, trimethoprim and sulphamethoxazole, chloroquine phosphate or pyrimethamine (Lester 1986). All these chemical treatments were ineffective in controlling or destroying the parasites, and even resulted in killing the oysters. Once shed into the environment, propagules of Marteilia are apparently short-lived. Trials on M. sydneyi spores revealed that treatment with $200 \mathrm{ppm}$ of chlorine kills $99.5 \%$ of the spores within 2 hours and $100 \%$ within 4 hours (Wesche et al. 1999). These results could be used to control the disease in closed or semi closed systems such as claire ponds (Audemard et al. 2001) or effluents of stocking facilities.

It should be noted that a hyper-parasite described in M. refringens has been reported (Comps et al. 1979). Nosema ormieresi (Microspora) was described as a hyper-parasite of $M$. refringens, causing necrotic changes such as primary cell and sporangia degeneration, membrane alteration, cytoplasm condensation and reduction in the number of spores. Authors suggested that this parasite has potential as biological control agent. However, since its initial description, this parasite has never been reported and due to its apparent rarity in the natural 
environment and the unknown mode of transmission, the possibility of biological control appears remote at present.

\section{Conclusion, open questions and way forward}

This review paper was focused on taxonomy, epidemiology, pathology, diagnosis and potential control methods of paramyxean parasites in order to foster better understanding of paramyxean infection issues in mollusc aquaculture. After more than thirty years of existence in the scientific literature, these organisms still pose questions requiring significant research by investigators.

Biodiversity of the group is believed to be underestimated given that little attention has been paid to parasites of non economic species even in the field of marine ecology. Although there is a wealth of information on basic morphology of several species under consideration here, a major problem with this group has been the lack of comparison between different species and the inconsistency in describing the parasites adequately. Although phylogeny and taxonomy of Paramyxea recently gained from DNA sequences, the need for more sequences is recognised, not only for systematic purposes but also to design and develop accurate diagnostic tools as well as research instruments targeted at investigations of their biology. Reports on paramyxean occurrence have often been based on few observations and small sample sizes of examined animals. Consequently, information such as temporal, spatial and other environmental data has been lacking, also probably misleading interpretations of published results and contributing to perpetuated mistakes that are now accepted as facts. This review is expected to alert scientists and lead to improved approach to studies of these organisms in the future.

The knowledge we have of paramyxeans is based on a relatively high number of studies and papers. Reviewing these papers, the overall picture highlights the lack of specific data required to develop biological models of these organisms. Lack of tools such as parasite or tissue culture, experimental disease transmission, etc., strongly impede upstream experimental research and limit scientists to applied studies in response to aquaculture sector concerns. However, fundamental questions of cellular development, pathogenesis and host pathogen relationships are posed by paramyxeans, and, by gaining an understanding of them, would allow the best chance of achieving control of these parasites in culture systems. Progress made in life-cycle investigations pleads for a multi-disciplinary approach to marine invertebrate parasitology in which not only molecular biology but also ecology and epidemiology are to play a pivotal role.

Within this framework, directed towards a better understanding of paramyxean parasites in marine invertebrates, three major axes may be identified. One is the continuously improved description of species and group delineation using a polyphasic approach to taxonomy. Second is the use of biological information and scientific data in an attempt to model the disease and forecast its impact in aquaculture systems. The third axis of investigation would consist of exploring relationships between the most well known species of paramyxeans, Marteilia refringens, M. maurini and their respective hosts,
Ostrea edulis and Mytilus spp., and M. sydneyi and its host Saccostrea glomerata, in order to better understand disease emergence and disease resistance in molluscs.

\section{References}

Adlard R.D., Ernst I., 1995, Extended range of the oyster pathogen Marteilia sydneyi. Bull. Eur. Assoc. Fish Pathol. 15, 119-121.

Alderman D.J., 1979, Epizootiology of Marteilia refringens in Europe. Mar. Fish. Rev. 41, 67-69.

Anderson T.J., Lester R.J.G., 1992, Sporulation of Marteilioides branchialis n. sp. (Paramyxea) in the sydney rock oyster, Saccostrea commercialis (Angas). J. Fish Dis. 18, 507-510.

Anderson T.J., McCaul T.F., Boulo V., Robledo J.A.F., Lester R.J.G., 1994, Light and electron immunohistochemical assays on paramyxean parasites. Aquat. Living Resour. 7, 47-52.

Anderson T.J., Wesche S., Lester R.J.G., 1994b, Are outbreaks of Marteilia sydneyi in Sydney rock oysters, Saccostrea commercialis, triggered by drop in environmental $\mathrm{pH}$ ? Aust. J. Mar. Freshwater Res. 45, 1285-1287.

Anderson T.J., Adlard R.D., Lester R.J.G., 1995, Molecular diagnosis of Marteilia sydneyi (Paramixea) in the Sydney rock oyster, Saccostrea commercialis (Angas). J. Fish Dis. 18, 507-510.

Andreadis S.T.G., 1988, Comparative susceptibility of the copepod Acanthocyclops vernalis to a Microsporidian parasite, Amblyospora connecticus, from the mosquito Aedes cantator. J. Invertebr. Pathol. 52, 73-77.

Audemard C., Barnaud A., Collins C.M., Le Roux F., Sauriau P.G., Coustau C., Blachier P., Berthe F.C.J., 2001, Claire ponds as an experimental model for Marteilia refringens life-cycle studies: new perspectives. J. Exp. Mar. Biol. Ecol. 257, 87-108.

Audemard C., Le Roux F., Barnaud A., Collins C., Sautour B., Sauriau P.-G., de Montaudouin X., Coustau C., Combes C., Berthe F.C.J., 2002, Needle in a haystack: involvement of the copepod Paracartia grani in the life cycle of the oyster pathogen Marteilia refringens. Parasitology 124, 315-323.

Auffret M., Poder M., 1983, Recherches sur Marteilia maurini, parasite de Mytilus edulis sur les côtes de Bretagne nord. Rev. Trav. Inst. Pêches Mar. 47, 105-109.

Auffret M., Poder M., 1987, Pathology of the main bivalve mollusc species from oyster rearing areas in Brittany (France). Aquaculture 67, 255-257.

Balouet G., 1979, Marteilia refringens - Considerations of the life cycle and development of Aber disease in Ostrea edulis. Mar. Fish. Rev. 41, 64-66.

Balouet G., Cahour A., Chastel C., 1979a, Epidémiologie de la maladie de la glande digestive de l'huître plate: hypothèse sur le cycle de Marteilia refringens. Haliotis 8, 323-326.

Balouet G., Chastel C., Cahour A., Quillard A., Poder M., 1979b, Étude épidémiologique et pathologique de la maladie de l'huître plate en Bretagne. Sci. Pêche 289, 13-22.

Becker C.D., Pauley G.B., 1968, An ovarian parasite (Protista incertae sedis) from the pacific oyster, Crassostrea gigas. J. Invertebr. Pathol. 12, 425-437.

Berthe F.C.J., 2000, Development and validation of DNA-based diagnostic techniques with particular reference to bivalve mollusc pathogens. In: DNA-based Molecular Diagnostic Techniques. Research needs for standardization and validation of the detection of aquatic animal pathogens and diseases. FAO Fish. Tech. Pap. 395, 64-70.

Berthe F.C.J., 2002, Pacem in terris pathogenibus bonae voluntatis. Bull. Eur. Assoc. Fish Pathol. 22, 4-9. 
Berthe F.C.J., Burreson E., Hine M., 1999, Use of molecular tools for mollusc disease diagnosis. Bull. Eur. Assoc. Fish Pathol. 19, 277-278.

Berthe F.C.J., Le Roux F., Peyretaillade E., Peyret P., Rodriguez D., Gouy M., Vivarès C.P., 2000, The existence of the phylum Paramyxea Desportes and Perkins, 1990 is validated by the phylogenetic analysis of the Marteilia refringens small subunit ribosomal RNA. J. Euk. Microbiol. 47, 288-293.

Berthe F.C.J., Pernas M., Zerabib M., Haffner P., Thébault A., Figueras A.J., 1998, Experimental transmission of Marteilia refringens with special considerations for its life cycle. Dis. Aquat. Org. 34, 135-144.

Bonami J.P., Grizel H., Vago C., 1971, Recherches sur une maladie épizootique de l'huître plate, Ostrea edulis Linné. Rev. Trav. Inst. Pêches Mar. 35, 415-418.

Bougrier S., Tigé G., Bachère E., Grizel H., 1986, Ostrea angasi acclimatization to French coasts. Aquaculture 58, 151-154.

Bower S.M., McGladdery S.E, Price I.M., 1994, Synopsis of infectious diseases and parasites of commercially exploited shellfish. Ann. Rev. Fish Dis. 4, 1-199.

Cahour A., 1979, Marteilia refringens and Crassostrea gigas. Mar. Fish. Rev. 41, 19-20.

Camacho A.P., Villalba A., Beiras R., Labarta U., 1997, Absorption efficiency and condition of cultured mussels (Mytilus edulis galloprovincialis Linnaeus) of Galicia (NW Spain) infected by parasites Marteilia refringens Grizel et al. and Mytilicola intestinalis Steuer. J. Shellfish Res. 16, 77-82.

Carballal M.J., Villalba A., Lopez C., 1998, Seasonal variation and effects of age, food availability, size, gonadal development and parasitism on the hemogram of Mytilus galloprovincialis. J. Invertebr. Pathol. 72, 304-312.

Cavalier-Smith T., Chao E.E.Y., 2003a, Phylogeny of Choanozoa, Apusozoa, and other protozoa and early eukaryote megaevolution. J. Mol. Evol. 56, 540-563.

Cavalier-Smith, T., Chao E.E.Y., 2003b, Phylogeny and classification of phylum Cercozoa (Protozoa). Protist 154, 341-358.

Ceschia G., Mion A., Orel G., Giorgetti G., 1992, Indagine parassitologica delle mitillicolture del Friuli-Venezia Giulia (Nord-Est Italia). Bol. Soc. Ital. Patol. Ittica 9, 24-36.

Ceschia G., Zanchetta S., Sello M., Montesi F., Figueras A., 2001, Presenza di parassiti in cannolicchi (Ensis minor e Ensis siliqua) pescati nell'area costiera del Mar Tirreno meridionale e del Mar Adriatico. Bol. Soc. Ital. Patol. Ittica 13, 20-27.

Chatton E., 1911, Sur une Cnidosporidie sans cnidoblaste (Paramyxa paradoxa, n.g., n.sp.). C. R. Acad. Sci. Paris 152, 631-633.

Chun S.K., 1970, Studies on the oyster diseases. 1. Pathogenetic Investigation. Bull. Korean Fish. Soc. 3, 7-17.

Chun S.K., 1972, Preliminary studies on the sporozoan parasites in oysters on the Southern Coast of Korea. Bull. Korean Fish. Soc. 5, 76-82.

Chun S.K., 1979, Amoeba infection in oyster (Crassostrea gigas). Bull. Korean Fish. Soc. 12, 281-285.

Combes C., 1995, Interactions durables : écologie et évolution durable du parasitisme. Masson, Paris.

Comps M., 1970, Observations sur les causes d'une mortalité anormale des huîtres plates (Ostrea edulis L.) dans le bassin de Marennes. Rev. Trav. Inst. Pêches Mar. 34, 317-326.

Comps M., 1976, Marteilia lengehi n. sp., parasite de l'huître Crassostrea cucullata Born. Rev. Trav. Inst. Pêches Mar. 40, 347-349.

Comps M., 1983, Étude morphologique de Marteilia christenseni sp. n. parasite du lavignon Scrobicularia piperata P. (mollusque pélécypode). Rev. Trav. Inst. Pêches Mar. 47, 99-104.
Comps M., Grizel H., Tigé G., Duthoit J.L., 1975, Parasites nouveaux de la glande digestive des mollusques marins Mytilus edulis L. et Cardium edule. C.R. Acad. Sci. Paris Sér. D. 281, 179-181.

Comps M., Joly J.-P., 1980, Contamination expérimentale de Mytilus galloprovincialis Lmk par Marteilia refringens. Sci. Pêche 301, 19-21.

Comps M., Park M.S., Desportes N., 1986, Étude ultrastructurale de Marteilioides chungmuensis n.g., n.sp. parasite des ovocytes de l'huître Crassostrea gigas Th. Protistologica 22, 279-285.

Comps M., Park M.S., Desportes I., 1987, Fine structure of Marteilioides chungmuensis n.g., n.sp., parasite of the oocytes of the oyster Crassostrea gigas. Aquaculture 67, 264-265.

Comps M., Pichot Y., Deltreil J.-P., 1979, Mise en evidence d'une microsporidie parasite de Marteilia refringens agent de la maladie de la glande digestive de Ostrea edulis L. Rev. Trav. Inst. Pêches Mar. 43, 409-412.

Comps M., Pichot Y., Papayianni P., 1982, Recherche sur Marteilia maurini n. sp. parasite de la moule Mytilus galloprovincialis Lmk. Rev. Trav. Inst. Pêches Mar. 45, 211-214.

Comps M., Tigé G., Grizel H., 1980, Recherches ultrastructurales sur un Protiste parasite de l'huître plate Ostrea edulis. C. R. Acad. Sci. Paris 290, 383-384.

Corliss J.O., 1984, The kingdom Protista and its 45 phyla. Biosystems 17, 87-126.

Cunningham C., 2002, Molecular diagnosis of fish and shellfish diseases: present status and potential use in disease control. Aquaculture 206, 19-55.

Desportes I., 1981, Étude ultrastructurale de la sporulation de Paramyxa paradoxa Chatton (Paramyxida) parasite de l'annélide polychète Poecilochaetus serpens. Protistologica 17, 365-386.

Desportes I., 1984, The Paramyxea Levine, 1979, An original example of evolution towards multicellularity. Origins of Life 13, 343-352.

Desportes I., Ginsburger-Vogel T., 1977a, Affinités du genre Marteilia, parasite d'huîtres (maladie des Abers). et du crustacé Orchestia gammarellus (Pallas), avec les Myxosporidies, Actinomyxidies et Paramyxidies. C.R. Acad. Sci. Paris 292, 627-632.

Desportes I., Ginsburger-Vogel T., 1977b, Ultrastructure du centriole de Marteilia sp., protiste parasite d'Orchestia gammarellus (Pallas) (Crustacé, Amphipode). Protistologica 13, 607-610.

Desportes I., Lom J., 1981, Affinités de Paramyxa paradoxa Chatton, 1911, parasite de Poecilochaetus serpens (Annélide polychète) avec les Marteiliidae Sprague, parasites d'huîtres et du crustacé Orchestia gammarellus. C.R. Acad. Sci. Paris 292, 627-632.

Desportes I., Nashed N.N., 1983, Ultrastructure of sporulation in Minchinia dentali (Arvy), an haplosporean parasite of Dentalium entale (Scaphopoda, Mollusca), taxonomic implications. Protistologica 19, 435-460.

Desportes I., Perkins F.O., 1990, Phylum Paramyxea. In: L. Margulis, J.O. Corliss, M. Melkonian, D.J. Chapman (Eds.), Handbook of Protoctista. Boston, Jones and Bartlett Publishing, pp. 30-35.

Elston R.A., 1993, Infectious diseases of the Pacific oyster, Crassostrea gigas. Ann. Rev. Fish Dis. 3, 259-276.

Figueras A.J., Jardon C.F., Caldas J.R., 1991, Diseases and parasites of rafted mussels (Mytilus galloprovincialis Lmk): preliminary results. Aquaculture 99, 17-33.

Figueras A.J., Montes J., 1988, Aber disease of edible oysters caused by Marteilia refringens. Am. Fish. Soc. Spec. Publ. 18, 38-46.

Figueras A.J., Robledo J.A.F., Novoa B., 1996, Brown ring disease and parasites in clams (Ruditapes decussatus and R. philippinarum) from Spain and Portugal. J. Shellfish Res. 15, 363-368. 
Franc A., 1980, Sur quelques aspects inédits du cycle de Marteilia refringens (Grizel et al. 1974), parasite de l'huître plate Ostrea edulis L. Cah. Biol. Mar. 21, 99-106.

Fuentes J., Lopez J.L., Mosquera E., Vazquez J., Villalba A., Alvarez G., 2002, Growth, mortality, pathological conditions and protein expression of Mytilus edulis and M. galloprovincialis crosses in the Ria de Arousa (NW of Spain). Aquaculture, 213, 233-251.

Fuentes J., Villalba A., Zapata C., Alvarez G., 1995, Effects of stock and culture environment on infections by Marteilia refringens and Myticola intestinalis in the mussel Mytilus galloprovincialis cultured in Galicia (NW Spain). Dis. Aquat. Org. 21, 221-226.

Ginsburger-Vogel T., 1991, Intersexuality in Orchestia mediterranea Costa, 1853, and Orchestia aestuarensis Wildish, 1987 (Amphipoda): A consequence of hybridisation or parasitic infestation? J. Crust. Biol. 11, 530-539

Ginsburger-Vogel T., Desportes I., 1979a, Structure and biology of Marteilia sp. in the amphipod, Orchestia gammarellus. Mar. Fish. Rev. 41, 3-7

Ginsburger-Vogel T., Desportes I., 1979b, Étude ultrastructurale de la sporulation de Paramarteilia orchestiae gen. n. sp.n. parasite de l'amphipode Orchestia gammarellus Pallas. Protistologica 26, 390-403.

Ginsburger-Vogel, T., Desportes, I., Zerbib, C., 1976, Présence chez l'amphipode Orchestia gammarellus (Pallas). d'un protiste parasite, ses affinités avec Marteilia refringens agent de l'épizootie de l'huître plate. C.R. Acad. Sci. Paris 283, 939-942.

Goulletquer P., Héral M., 1997, Marine Molluscan Production Trends in France: From Fisheries to Aquaculture. In: C.L. Mackensie, V.G. Bunell, A. Rosenfield (Eds.). The history, present condition, and future of the Molluscan fisheries of North America and Europe, vol. 3. Europe. NOAA Tech. 1 Rep. NMFS 129, Seattle, Washington, US Dep. Commerce, pp. 137-164.

Grizel H., 1979, Marteilia refringens and oyster disease - recent observations. Mar. Fish. Rev. 41, 38-39.

Grizel H., 1985, Étude des récentes épizooties de l'huître plate (Ostrea edulis Linné) et leur impact sur l'ostréiculture bretonne. Thèse Doctorat es Sciences, Univ. Sciences et Techniques du Languedoc, Montpellier.

Grizel H., 1997, Les maladies des mollusques bivalves : risques et prévention. Rev. Scient. Tech. Off. Int. Epizoot. 16, 161-171.

Grizel H., Comps M., Bonami J.R., Cousserans F., Duthoit J.L., Le Pennec M.A., 1974, Recherche sur l'agent de la maladie de la glande digestive de Ostrea edulis Linné. Sci. Pêche 240, 7-29.

Grizel H., Comps M., Raguenes D., Leborgne Y., Tigé G., Martin A.G., 1982, Bilan des essais d'acclimatation d'Ostrea chilensis sur les côtes de Bretagne. Rev. Trav. Inst. Pêches Marit. 46, 209-225.

Grizel H., Héral M., 1991, Introduction into France of the Japanese oyster Crassostrea gigas. J. Cons. Internat. Explor. Mer. 47, 399-403.

Grizel H., Tigé G., 1973, La maladie de la glande digestive d'Ostrea edulis Linné. ICES CM K 13, 1-7.

Gutierrez M., 1977, Tecnica de coloracion del agente de la enfermedad de la glandula digestiva de la ostra plana, Ostrea edulis L. Invest. Pesq. 41, 643-645.

Herrbach B., 1971, Sur une affection parasitaire de la glande digestive de l'huître plate, Ostrea edulis Linné. Rev. Trav. Inst. Pêches Mar. 35, 79-87.

Hide G., Tait A., 1991, The molecular epidemiology of parasites. Experientia 47, 128-140.

Hine P.M., 1996, Southern hemisphere mollusc diseases and an overview of associated risk assessment problems. Rev. Scient. Tech. Off. Int. Epizoot. 15, 563-577
His E., Tigé G., Rabouin M.A., 1976, Observations relatives à la maladie des huîtres plates dans le bassin d'Arcachon, vitesse d'infestation et réactions pathologiques. ICES CM K, 17.

Howard D.H., Smith C.S., 1983, Histological techniques for marine bivalve molluscs. NOAA Tech. Memorandum NMFS-F/NEC, 25.

Imanaka S., Itoh N., Ogawa K., Wakabayashi H., 2001, Seasonal fluctuations in the occurrence of abnormal enlargement of the ovary of Pacific oyster Crassostrea gigas at Gokasho Bay, Mie, Japan. Fish Pathol. 36, 83-91.

Itoh N., Oda T., Yoshinaga T., Ogawa K., Wakabayashi H., 2002, Identification and development of paramyxean ovarian parasite in the Pacific oyster Crassostrea gigas. Fish Pathol. 37, 23-28.

Itoh N., Oda T., Yoshinaga T., Ogawa K., 2003, Isolation and 18S ribosomal DNA gene sequences of Marteilioides chungmuensis (Paramyxea), an ovarian parasite of the Pacific oyster Crassostrea gigas. Dis. Aquat. Org. 54, 163-169.

Kleeman S.N., Adlard R.D., 2000, Molecular detection of Marteilia sydneyi, pathogen of Sydney rock oysters. Dis. Aquat. Org. 40, 137-146.

Kleeman S.N., Adlard R., Lester R., 2002a, Detection of the initial infective stages of the protozoan parasite Marteilia sydneyi in Saccostrea glomerata and their development through to sporogenesis. Int. Parasitol. 32, 767-784.

Kleeman S.N., Adlard R.D., Zhu X.Q., Gasser R.B., 2004, Mutation scanning analysis of Marteilia sydneyi populations from different geographical locations in eastern Australia. Mol. Cell. Probes 18, 133-138

Kleeman S.N., Le Roux F., Berthe F., Adlard R.D., 2002b, Specificity of PCR and in situ hybridisation assays designed for detection of Marteilia sydneyi and M. refringens. Parasitology 125, 131-141.

Launey S., Barre M., Gérard A., Naciri-Graven Y., 2001, Population bottleneck and effective size in Bonamia ostreae-resistant populations of Ostrea edulis as inferred by microsatellite markers. Genet. Res. 78, 259-270.

Le Roux F., Audemard C., Barnaud A., Berthe F.C.J., 1999, DNA probes as potential tools for the detection of Marteilia refringens. Mar. Biotechnol. 1, 588-597

Le Roux F., Lorenzo G., Peyret P., Audemard C., Figueras A., Vivarès C., Gouy M., Berthe F.C.J., 2001, Molecular evidence for the existence of two species of Marteilia in Europe. J. Euk. Microbiol. 48, 449-454.

Lee M.K., Cho B.Y., Lee S.Y., Kang J.Y., Joeng H.D., Huh S.H., Huh M.D., 2001, Histopathological lesions of Manila clam, Tapes philippinarum, from Hadong and Namhae coastal areas of Korea. Aquaculture 201, 199-209.

Lester R.J.G., 1986, Field and laboratory observations on the oyster parasite Marteilia sydneyi. In: M. Cremin, C. Dobson, D.E. Moorhouse (Eds.). Parasite lives- Papers on parasites, their hosts and their associations St. Lucia, University of Queensland Press, pp. 33-40.

Levine N.D., Corliss J.O., Cox F.E.G., Deroux G., Grain J., Honiberg B.M., Leedale G.F., Loeblich A.R., Lom J., Lynn D., Merinfeld E.G., Page F.C., Poljansky G., Sprague V., Vavra J., Wallace F.G., 1980, A newly revised classification of the Protozoa. J. Protozool. 27, 37-58.

Longshaw M., Feist S.W., Matthews A., Figueras A., 2001, Ultrastructural characterisation of Marteilia species (Paramyxea) from Ostrea edulis, Mytilus edulis and Mytilus galloprovincialis in Europe. Dis. Aquat. Org. 44, 137-142.

Lopez-Flores I., de la Herran R., Garrido-Ramos M.A., Navas J.I., Ruiz-Rejon C., Ruiz-Rejon M., 2004, The molecular diagnosis of Marteilia refringens and differentiation between Marteilia strains infecting oysters and mussels based on the rDNA IGS sequence. Parasitology 129, 411-419. 
Lubat V., 1990, Approches biologiques et moléculaires dans l'étude des myxosporidies, du PKX et des Marteilia. Thèse Doctorat es Sciences, Univ. Sciences et Techniques du Languedoc, Montpellier.

Matsuzato T., Hoshina T., Arakawa K., Masumura K., 1977, Studies on the so-called abnormal egg-mass of Japanese oyster, Crassostrea gigas (Thunberg)- I. Bull. Hiroshima Fish. Exp. St. 8, 9-25.

Mialhe E., Bachère E., Boulo V., Cadoret J.P., Saraiva J., Carrera L., Rousseau C., Cedeno V., Calderon J., Colwell R.R., 1995, Future of biotechnology-based control of disease in marine invertebrates. Mol. Mar. Biol. Biotechnol. 4, 275-283.

Miahle E., Bachère E., Le Bec C., Grizel H., 1985, Isolement et purification de Marteilia (Protozoa: Ascetospora) parasites de bivalves marins. C. R. Acad. Sci. Paris 301, Ser. III, 137-142.

Micieli M.V., Garcia J.J., Becnel J.J., 2000, Horizontal transmission of Amblyospora albifasciati Garcia and Becnel, 1994 (Microsporidia: Amblyosporidae), to a copepod intermediate host and the neotropical mosquito, Aedes albifasciatus (Macquart 1837). J. Invertebr. Pathol. 75, 76-83.

Montaudouin de X., Sauriau P.-G., 2000, Contribution to a synopsis of marine species richness in the Pertuis Charentais Sea with new insight in soft-bottom macrofauna of the Marennes-Oléron Bay. Cah. Biol. Mar. 41, 181-222.

Moyer M.A., Blake N.J., Arnold W.S., 1993, An ascetosporan disease causing mass mortality in the Atlantic calico scallop, Agropecten gibbus (Linnaeus 1758). J. Shellfish Res. 12, 305-310.

Nell J.A., Smith I.R., Hand R.E., McPhee C.C., 2000, The Sydney rock oyster Saccostrea glomerata (Gould 1850) breeding programme: progress and goals. Aquac. Res. 31, 45-49.

Newton K., Peters R., Raftos D., 2004, Phenyloxidase and QX disease resistance in Sydney rock oysters (Saccostrea glomerata). Dev. Comp. Immunol. 28, 565-569.

Ngo T.T.T., Berthe F.C.J., Choi K.S., 2003, Prevalence and infection intensity of the ovarian parasite Marteilioides chungmuensis during an annual reproductive cycle of the oyster Crassostrea gigas. Dis. Aquat. Org. 56, 259-267.

Norton J.H., Perkins F.P., Ledua E., 1993, Marteilia-like infection in a giant clam, Tridacna maxima, in Fiji. J. Invertebr. Pathol. 61, 328-330.

OIE, 2003, Diagnostic Manual for Aquatic Animal Diseases. OIE, Paris. Fourth edition.

OIE, 2003, International Aquatic Animal Health Code. OIE, Paris. Sixth edition.

Park M.S., Chun S.K., 1989, On the Marteilia sp. infection in the oyster, Crassostrea gigas (Thunberg). Bull. Fish. Res. Dev. Agency 39, 103-109.

Pascual M., Martin A.G., Zampatti E., Coatanea D., Defossez J., Robert R., 1991, Testing of the Argentina oyster, Ostrea puelchana in several French oyster farming sites. ICES Council Meeting Pap. CM 1991/K, 30.

Perkins F.O., 1976, Ultrastructure of sporulation in the European flat oyster pathogen, Marteilia refringens - Taxonomic implications. J. Protozol. 23, 64-74.

Perkins F.O., 1979, Cell structure of shellfish pathogens and hyperparasites in the genera Minchinia, Urosporidium, Haplosporidium and Marteilia Taxonomic implications. Mar. Fish. Rev. 41, 25-37.

Perkins F.O., 1988, Parasite morphology, strategy and evolution. Structure of protistan parasites found in bivalve molluscs. Am. Fish. Soc. Spec. Publ. 18, 93-11.
Perkins F.O., 1993, Infectious diseases of molluscs. In: Couch J.A., Fournie J.W. (Eds.). Advances in Fisheries Science: Pathobiology of marine and estuarine organisms Boca Raton, CRC Press, pp. 255-287.

Perkins F.O., Wolf P.H., 1976, Fine structure of Marteilia sydneyi sp. n. Haplosporidian pathogen of Australian oysters. J. Parasitol. 62, 528-538.

Pernas M., Novoa B., Tafalla C., Figueras A., 2000, Efficiency of different monoclonal antibodies in immunological assays developed for the detection of Marteilia sp. isolated from Mytilus galloprovincialis. Bull. Eur. Assoc. Fish Pathol. 20, 193-198.

Peters R., Raftos D.A., 2003, The role of phenyloxidase suppression in QX disease outbreaks among Sydney rock oysters (Saccostrea glomerata). Aquaculture 223, 29-39.

Peyretaillade E., Biderre C., Peyret P., Duffieux F., Méténier G., Gouy M., Michot B., Vivarès C.P., 1998, Microsporidian Encephalitozoon cuniculi, a unicellular eukaryote with an unusual chromosomal dispersion of ribosomal genes and a LSU rRNA reduced to the universal core. Nucleic Acid Res. 26, 3513-3520.

Poder M., Auffret M., Balouet G., 1983, Études pathologiques et épidémiologiques des lésions parasitaires chez Ostrea edulis L. premiers résultats d'une recherche prospective comparative chez les principales espèces de mollusques des zones ostréicoles de Bretagne nord. Colloques sur les bases biologiques de l'aquaculture, Dec. 12-16, 1983. CNRS-CNEXO, Montpellier, pp. 125-138.

Renault T., Cochennec N., Chollet B., 1995, Marteiliosis in American oysters Crassostrea virginica reared in France. Dis. Aquat. Org. 23, 161-164.

Riera V., Santmarti M., Durfort M., 1993, Presencia de Marteilia refringens en los cultivos de moluscos bivalvos del litoral Catalan. Actas IV Congreso Nac. Acuicult. pp. 539-544.

Robert R., Borel M., Pichot Y., Trut G., 1991, Growth and mortality of the European oyster Ostrea edulis in the Bay of Arcachon (France). Aquat. Living Resour. 4, 265-274.

Robledo J.A.F., Boulo V., Mialhe E., Desprès B., Figueras A., 1994b, Monoclonal antibodies against sporangia and spores of Marteilia sp. (Protozoa: Ascetospora). Dis. Aquat. Org. 18, 211-216.

Robledo J.A.F., Caceres-Martinez J., Figueras A., 1994a, Marteilia refringens in mussel (Mytilus galloprovincialis Lmk) beds in Spain. Bull. Eur. Assoc. Fish Pathol. 14, 61-63.

Robledo J.A.F., Figueras A.J., 1995, The effects of culture-site, depth, season and stock source on the prevalence of Marteilia refringens in cultured mussels (Mytilus galloprovincialis Lmk.) from Galicia, Spain. J. Parasitol. 81, 354-363.

Robledo J.A.F., Miahle E., Figueras A., 1995b, Purification of several phases of the parasite Marteilia (Protozoa: Ascetospora) from mussels (Mytilus galloprovincialis). In: J.C. Stolen, T.C. Fletcher, S.A. Smith, J.T. Zelikoff, S.L. Kaattari, R.S. Anderson, K. Soderhall, B.A. Weeks-Perkins (Eds.). Techniques in fish immunology - 4. Immunology and pathology of aquatic invertebrates. SOS Publications, Fair Haven, NJ, USA, pp. 117-121.

Robledo J.A.F., Santarem M.M., Gonzalez P., Figueras A., 1995a, Seasonal variations in the biochemical composition of the serum of Mytilus galloprovincialis Lmk. and its relationship to the reproductive cycle and parasitic loads. Aquaculture 133, 311-322.

Roubal F.R., Masel J., Lester R.J.G., 1989, Studies on Marteilia sydneyi, agent of QX disease in the Sydney rock oyster, Saccostrea commercialis, with implications for its life cycle. Aus. J. Mar. Freshwater Res. 40, 155-167.

Sautour B., 1991, Populations zooplanctoniques dans le bassin de Marennes-Oléron, dynamique de population, nutrition et production des copépodes dominants. Thèse Dr., Université Bordeaux I. 
Siddall M.E., Martin D.S., Bridge D., Dessewr S.S., Cone D.K., 1995, The demise of a phylum of protists: Phylogeny of Myxozoa and other parasitic Cnidaria. J. Parasitol. 81, 961-967.

Sprague V., 1979, Classification of the Haplosporidia. Mar. Fish. Rev. 41, 40-44.

Sprague V., 1982, Ascetospora. In: Parker S.P. (Ed.). Synopsis and classification of living organisms, Vol. 1. McGraw-Hill Book Company, New York, pp. 599-601.

Stiller J.W., Hall B.D., 1999, Long branch attraction and the rDNA model of eukaryotic evolution. Mol. Biol. Evol. 16, 1270-1279.

Thoeson J.C., 1994, Suggested Procedures for the Detection and Identification of Certain Finfish and Shellfish Pathogens, Fifth Edition. Bluebook, American Fisheries Society, Bethesda, USA.

Tigé G., Rabouin M.A., 1976, Étude d'un lot de moules transférées dans un centre touché par l'épizootie affectant l'huître plate. CIEM CM,K21, 1-10.

Tiscar P.G., Tempesta M., Compagnucci M., 1993, Peroxidase conjugated polyclonal antibody against Marteilia sp. purified from infected mussels (Mytilus galloprovincialis Lmk) cultivated in Apulia, southern Italy. Bull. Eur. Assoc. Fish Pathol. 13, 53-55.

Van Banning P., 1979, Haplosporidian diseases of imported oysters Ostrea edulis, in Dutch Estuaries. Mar. Fish. Rev. 41, 8-18.

Van Banning P.J., 1988, Management strategies to control diseases in the Dutch culture of edible oysters. In: Couch J.A., Fournie J.W. (Eds.). Advances in Fisheries Science, Pathobiology of marine and estuarine organisms. Boca Raton, CRC Press, pp. 243-245.

Villalba A., Mourelle S.G., Carballal M.J., Lopez M.C., 1993b, Effects of infection by the protistan parasite Marteilia refringens on the reproduction of cultured mussels Mytilus galloprovincialis in Galicia (NW Spain). Dis. Aquat. Org. 17, 205-213.
Villalba A., Mourelle S.G., Lopez M.C., Carballal M.J., Azevedo C., 1993a, Marteiliasis affecting cultured mussels Mytilus galloprovincialis of Galicia (NW. Spain). I. Etiology, phases of the infection, and temporal and spatial variability in prevalence. Dis. Aquat. Org. 16, 61-72.

Walker P., Subasinghe R.P., 2000, DNA-based Molecular Diagnostic Techniques. Research needs for standardization and validation of the detection of aquatic animal pathogens and diseases. FAO Fish. Tech. Pap. 395.

Wesche S.J., 1995, Outbreaks of Marteilia sydneyi in Sydney rock oysters and their relationship with environmental pH. Bull. Eur. Assoc. Fish Pathol. 15, 23-27.

Wesche S.J., Adlard R.D., Lester R.J.G., 1999, Survival of spores of the oyster pathogen Marteilia sydneyi (Protozoa, Paramyxea) as assessed using fluorogenic dyes. Dis. Aquat. Org. 36, 221-226.

Wolf P.H., 1972, Occurrence of a Haplosporidian in Sydney rock oysters (Crassostrea commercialis) from Moreton Bay, Queensland, Australia. J. Invertebr. Pathol. 19, 416-417.

Wolf P.H., 1977, An unidentified protistan parasite in the ova of the blacklipped oyster, Crassostrea echinata, from Northern Australia. J. Invertebr. Pathol. 29, 244-246.

Wolf, 1979, Life cycle and ecology of Marteilia sydneyi in the Australian oyster, Crassostrea commercialis. Mar. Fish. Rev. 41, 70-72.

Zrncic S., Le Roux F., Oraic D., Sostaric B., Berthe F., 2001, First record of Marteilia sp. in mussels, Mytilus galloprovincialis in Croatia. Dis. Aquat. Org. 44, 143-148. 